\title{
An Analysis of Rabbit's Unhappy Marriage in John Updike's Rabbit Run
}

\author{
Min Zhang \\ General Education College \\ Heihe University \\ Heihe, China, 164300
}

\begin{abstract}
As we know, among contemporary American novelists, John Updike is one of the most talented writers on marriage fiction. There is no doubt that Rabbit, Run is the most representative one on marriage. In this paper, from the angle of traditional literature and art criticism, the motif of the novel-marriage is used as the main research object to analyze the hero's marriage case in the novel, which aims to figure out the reasons for the unhappy marriage, and the unsuccessful countermeasures taken for the unhappy marriage so as to provide some advice for readers to solve the similar problems in the marriage.
\end{abstract}

Keywords-marriage; cause; unsuccessful countermeasures

\section{INTRODUCTION}

John Hoyer Updike is regarded as a diligent, intelligent and prolific writer. However, Updike achieved recognition as a literary writer and became famous with the publication of his second novel Rabbit, Run in 1960. In Rabbit, Run, the protagonist Rabbit, a twenty-six-year-old man got married to Janice, a boredom woman always falling into a drunken situation. Each time he got to his small, squalid apartment and saw his wife pregnant with the second baby being ugly, unresponsive to him, he felt the nondescript irritation. At the moment, he was determined to run away instead of going to his mother-in-law's to get his son. Since then, he had been with a part-time prostitute, Ruth until Janice was going to labor. Janice gave birth to a girl baby. When returning to his apartment, Rabbit pressured Janice into having sex unsuccessfully. Feeling hunt and offended, Rabbit ran again. As a result, Janice drunk and accidentally drowned their infant daughter in the bath. Harry had to attend the funeral, but he refused to take the blame for the baby's death, which drew criticism for him, and ultimately he ran away once more. When returning to Ruth, he found her pregnant. Under such conditions, Rabbit felt that the life was like an invisible net and suffocated him, and thus he had to run away, leaving the ending of the novel in midair.

\section{THE CAUSES OF RABBIT'S UNFORTUNATE MARRIAGE}

There are many reasons that caused Rabbit's unfortunate marriage, but among them the following three reasons are the most direct ones.

\section{A. Psychological Immaturity}

Psychological maturity will have a significant impact on adapting to the marriage. Psychological maturity includes the following features: whether he has perseverance to face with the setbacks and difficulties he encounters, whether he can deal with them with a positive attitude and flexible approach, whether he has a basic confidence in himself, understands others and treats others considerately.

In Rabbit, Run, Rabbit, a twenty-six-year-old boy refuses to grow up. He and Janice share an unhappy marriage life. Janice drinks too much, she is a poor housekeeper, she is sexually unresponsive, and she is dumb. All the shortcomings of Janice become the justification for Rabbit's plight. All the shortcomings seem to offer an evidence for Rabbit's unfortunate marriage life.

Furthermore, Jane's psychological immaturity directly affects her relationship with Rabbit as well as her ability to look after her children, Nelson and Rebecca. Like Rabbit, she wants to be the center of attention and her major strategy to get recognition is to arouse sympathy for her various problems. In their first scene together, Rabbit comes home from work to find her watching a children's television program and drinking, and Nelson is not at home. When asking her where the car is, Rabbit learns about that she is shopping with her mother all the day, and that makes her varicose and feels very tired. In spite of being slightly drunk, she is able to sense Rabbit's dissatisfaction. Janice manages to convert Rabbit's anger to pity which she immediately attempts to reinforce by describing her fatigue to him. Janice, always the victim, attempts to manipulate Rabbit and makes him feel sympathy for her while Rabbit also eager for attention is already fed up with the technique and asserts his need by ultimately denouncing Janice's claims on him. Every time they are together, Rabbit and Janice will repeat the same scene to one another without major variations, which ultimately leads to Rabbit's running away.

\section{B. Sexual Incompatibility}

Although sexual marriages are not necessarily happy, the harmonious sex undoubtedly is another important factor of marital happiness, especially for Rabbit, a man with a strong sexual desire. When the sexual ability is considered as a way to manifest his esteem as a man, embody his self-value and 
enhance his self-confidence, his sexual incompatibility with Janice undoubtedly is another major weakness in the marriage.

It is Janice's sexual spontaneity that initially attracts Rabbit. Before marriage, impatiently leaving work at Kroll's, Rabbit would hurry back to Janice's apartment for sex. Now three years later, her previous enthusiasm is "always an effort". Now she only wants to get Rabbit's sympathy and attention instead of her previous spontaneity. Sex for her is only a means used to control her husband and win the pity and attention from Rabbit. Just because she puts sex as bait, she has lost her passion for sex. When Rabbit hints to her that he has the sexual interest, she quickly shifts the conversation to her usual list of complaints.

However, on the other hand, Rabbit never stops thinking about sex. The lack of opportunity for sex in his marriage leaves him the fantasy to make love with other woman, and at the same time it is because of this that he soon has a crushing Ruth when she lets him get pleasure in sex. Repeatedly comparing Janice's physical appearance in the present with her past youthfulness, the idea that with the time passing by, Janice will lose everything, her young look, her attractive body etc. and become a meaningless and lifeless dead body which makes Rabbit full of fear. Although she is in her early twenties, Janice's wrinkles, thinner hair and her continual complaints to Rabbit transform her into a sexless object. Janice's prematurity and the past innocence with the passage of time make Rabbit who imagines that maturity is synonymous with the death of people full of fear when facing her.

Rabbit tries to ease the relationship with Janice nine days after she comes back home from the hospital. Regarding Janice's palliative attitude as a reward to him for rejecting Lucy Eccles, he wants Janice to repay him with sex through which we can see how important sex is in Rabbit's heart. Rabbit knows Janice will deny him with the excuse of her childbirth convalescence and fatigue; however, he still makes an attempt to force her to make love and then uses the rejection as an excuse for his escape.

\section{The Pressures Exerted upon the Young by Their Parents}

It is said that parents are the first teacher of their children. Parents' language and behavior usually have a significant effect on their children. In Rabbit, Run, Rabbit's mother always keeps the supreme status, relegating her husband and daughter to a subordinate position, while reserving for her son Rabbit the attention, she denied the others. However, Rabbit's mother is not satisfied with the domination to her husband. Nourishing Rabbit in his young as the center of her own emotion, she has been centered on her own rules to educate Rabbit. On the surface, it seems that she has devoted all her life to her son, but in fact she is trying to find herself in her son and gradually instill in him to respect her philosophy of behavior. To her great disappointment, Rabbit has been married to Janice in spite of her objection. Claiming her dominance over her husband and family, Mary hinted Rabbit that he was at the mercy of his wife which adds the fear of Rabbit to entrap himself into marriage. But at the same time, Mary helps her son find an excuse for abandoning his family.

In the heart of Mary Angstrom, Rabbit has been used to replace her husband, so when she sees Rabbit is at the mercy of Janice, she attempts to negate this. When Rabbit decides to reunite with Janice, she feels furious. There is no doubt Mary's determined dependence on him makes Rabbit confused about what to do on earth.

Protecting him from the world, Rabbit fails to realize that the true enemy of his independence is actually his mother, who has been trying to make Rabbit isolate himself from the world, and thereby has Rabbit attached to her further. Updike focuses much attention on the conflict between mother and son. From several running away of Rabbit, we can see clearly his mother's deformity of education is extremely unsuccessful. Rabbit must first get rid of his mother's influence and control over himself in order to start a new life with his new family.

\section{RABBIT'S COUNTERMEASURES FOR THE UNHAPPY MARRIAGE}

There are two main countermeasures that Rabbit took for his unhappy marriage, which were doomed to fail. So in the end, he had no choice but to run.

\section{A. Religious Measure for the Unhappy Marriage}

Rabbit is a typical American middle-class representative. He was devoutly religious when he was a young man. In Rabbit, Run, he claims that he is a Puritan and has sought the demeanor of their traditional standards. As a result, he does not smoke, or drink, and especially loves the clean, even his wife says he is like a saint. He is religious, loves the church, and thinks of God as the guide of all his words and deeds. Whenever he is in fear, the image of the church will appear in front of him. When he fled from his home for the first time, and had cohabitation together with Ruth, he was often staring at the windows of the church for a long time, hoping to get the power of the spirit, and find the lost meaning of life.

But when he fled for the last time, he changed the position of the church in his mind which previously gave him spiritual comfort. The church, a symbol of the bright before, now has changed into the darkness that he tried to break away from, which cannot provide any guidance to his behavior, and even he wants to cast it aside like a nightmare. So the illusion of trying to rely on the power of religion out of the predicament failed. What on earth made Rabbit have such a huge change on his religious views?

In fact, Harry can be considered as a religious. It is because of the loss of faith that causes his first escape. When he finds that life is meaningless, he abandons his wife and children, and leaves home to seek that self under the guidance of God. But his religion is not strong; he just treats it as a kind of spiritual sustenance to escape from the reality and a tool to solve practical problems. When religion cannot solve problems for him, and indicate a way out, his faith in God begins to shake. His daughter's death has him further 
suspect the existence of God and he even thinks God is to blame.

\section{B. Running as the Only Measure for the Unhappy Marriage}

In Rabbit, Run, Updike tells us a story about Harry's looking for- compromise- looking for again- eventually giving up, in which a social problem is reflected, that is the conflict between personal freedom and social permission degrees, and the conflict between personal desire and ethics.

In Harry's first two escapes, we can see his pursuit of self and freedom. Harry embarked on a vast road pursuing dreams. He did not know where to go, and how to arrive, just as he did not know that the repressed marriage life did not come from his wife and family but from the strong contrast between the expectations from his heart and the cruel social reality. The U.S. government promotes attention to personality, but does not provide the necessary social environment for Americans to emphasize themselves, which makes many young people like Harry lost in reality, and look for the 'American dream' in a panic state all the time. The third escape happened in his daughter's funeral. Since Janice was unable to withstand the blow that Harry had abandoned her again, unfortunately, she missed her daughter and drowned her when taking a bath for her. When Harry heard the news, he came back home, but at his daughter's funeral, Harry was embarrassed ,and full of shame, grievance, hatred, and panic, and then turned running away. After escaping from the funeral, Harry came to his lover, Ruth, but when learning the news of Ruth's pregnancy, Harry, a man of self supremacy, escaped from Ruth again because of fear of responsibility. From Harry's three escapes, we see the timid, selfish and irresponsible side in him.

Through such a plot, Updike tells us that in marriage, if you do not care about other people's feelings and are always irresponsibly pursuing stimulation and enjoyment, the ultimate end can only be to lose self in the blind escape, and destroy the family.

\section{CONCLUSION}

So in the face of modern marriage crisis, what should modern people do on earth to get out of an unhappy marriage dilemma? First, communicate your feelings respectfully. When you have issues, thoughts, or feelings, they need to be discussed and dealt with as they occur. Second, be a great listener. Listen to your partner when she needs to communicate. Try to listen and really hear instead of reacting. This takes practice, but it is well worth doing. Third, Trust your partner, and in turn be trustworthy. Trust is an integral component in a relationship. If there is mistrust, there can never be real comfort and companionship. Commit to being a partner who should be trusted, and hope that your partner develops the same mindset. Fourth, Respect and treasure your differences. Learn from one another. Appreciate and understand your spouse's distinctive style, approach and personality - especially when it diverges from yours. Differences can often turn into delight. Last but not least, sacrifice where it is necessary for the good of the marriage. Marriage is a dance of give and take. When both partners are giving to each other out of real love and devotion to meet the needs of each other, both partners will have their needs met. Instead of seeking to have your own needs met, seek to meet the needs of your partner. In this way, each partner will be caring for the other in the marriage.

\section{REFERENCES}

[1] Abram, M. H.Ed The NortonAnology of American Literature [M]. New York: Norton, 1979.

[2] Bloom, Harold. John Updike. New York: Chelsea House Publishers, 1987.

[3] Jung, Carl Gustav. The Spirit in Man, Art and Literature. London: Routledge, 2003.

[4] Plath James, ed. Conversations with John Updike. Jackson: University Press od Mississippi, 1994.

[5] Updike John, More Matter: Essays and Criticism. New York: Alfred A. Knopf, 1991.

[6] Updike John, Why Rabbit Had to Go, New York Times Book Review, 1990.

[7] Waldmeir, Joseph. It's the Going That's Important, Not the Getting There: Rabbit's Questing Non Quest. Modern Fiction Studies, 1974. 